\title{
Recovery of rare metals from spent lithium ion cells by hydrothermal treatment and its technology assessment
}

\author{
H. Itoh, H. Miyanaga, M. Kamiya \& R. Sasai \\ Division of Environmental Research, EcoTopia Science Institute, \\ Nagoya University, Japan.
}

\begin{abstract}
A novel cobalt recovering process from a cobalt-based cathode electrode in a lithium secondary cell was developed using a hydrothermal treatment combined with a pyrometallurgical technique. A cobalt-based cathode electrode was prepared by casting the mixture of $\mathrm{LiCoO}_{2}$, poly(vinylidene fluoride) and conductive carbon black onto an $\mathrm{Al}$ foil, and this model electrode was used as a test sample. A hydrothermal treatment of the cathode sample was carried out using pure water as a solvent in the temperature range of $423-473 \mathrm{~K}$ for the duration of $0-40 \mathrm{~h}$. The hydrothermal treatment at $473 \mathrm{~K}$ for more than $15 \mathrm{~h}$ led the cathode sample to the disintegration into powdery particles. By the hydrothermal treatment under the optimum condition at $473 \mathrm{~K}$ for $20 \mathrm{~h}$, more than 99.9 mass $\%$ of $\mathrm{Co}$ and 98 mass\% of $\mathrm{Al}$ in the cathode sample was reclaimed as a form of spinel type $\mathrm{Co}\left(\mathrm{Co}_{\mathrm{x}} \mathrm{Al}_{2-\mathrm{x}}\right) \mathrm{O}_{4}(0<\mathrm{x} \leq 2)$, and most of $\mathrm{Li}$ and $\mathrm{F}$ could be dissolved into the solution. Subsequently, metallic cobalt was successfully recovered from the spinel compound and carbon mixture by the pyrometallurgical treatment with additives for slag formation under a reducing condition at $1623 \mathrm{~K}$ for $5 \mathrm{~h}$.
\end{abstract}

Keywords: spent lithium ion cell, hydrothermal treatment, cobalt recovery, pyrometallurgical treatment.

\section{Introduction}

In the past one decade, lithium ion cell has been spreading its occupation in the world cell market because of its properties superior to other conventional secondary cells [1]. Due to its incomparable advantages, the lithium ion cell has been exploited for many electric appliances or even in a medical field [2]. Furthermore, the lithium ion cell contains less toxic metals comparing to the 
nickel-cadmium cell. Taking these overall advantages into consideration, it is quite explicit that the lithium ion cell will be equipped continuously in a number of new electric applications.

It has no doubt that a tremendous number of the spent lithium ion cells will be disposed when they reach the end of their practical life [3]. These wastes should be appropriately treated in order to recover cobalt in the spent cells since cobalt is classified as one of rare metals. The consumption of cobalt always leads to the market price appreciation due to little reserves of cobalt-containing ore in the earth's crust. In addition, a large amount of cobalt is demanded not only in lithium ion cells, but also in various sorts of industrial materials such as hard alloys, paints or magnets. Therefore, recovering cobalt from spent lithium ion cells is quite beneficial to solve the pressing problem on stable cobalt-supply.

Up to the present time, most of practical recycle process for the spent lithium ion cells is based on a pyrometallurgical method. This process mainly consisted of two heat-treatment stages, i.e., the gasification removal of lithium and fluorine in the spent cell, and the reduction and condensation of cobalt from the residue. It is obvious that this process needs less chemical reagents, but a large amount of energy is required for the whole heat-treatment processes. Additionally, there is a serious problem in the first heat-treatment stage that a furnace wall has a severe damage by corrosive gasses.

Recently, a cobalt reclamation process has been investigated by a hydrometallurgical technique of the cathode materials in the spent lithium cell. For example, Zhang et al. [4] attempted to recover cobalt from the cathode by three steps, i.e., (1) the cobalt dissolution step from the cathode using hydrochloric acid, (2) the extraction step from the leached liquid into kerosene and (3) the inverse extraction step with sulfuric acid to form cobalt sulfate. Nan et al. proposed another hydrometallurgical process, which was based on the dissolution-deposition and extraction methods [5]. These reports imply that cobalt-recovering process has an advantage from the standpoint of smaller energy consumption compared with the pyrometallurgical method; however, this process requires an appreciable amount of toxic chemicals or complex multistage-treatments.

In order to reduce the environmental loads arising from both the pyrometallurgical and hydrometallurgical treatments, we propose a novel cobaltrecovering process based on a hydrothermal technique, which is incorporated into the current pyrometallurgical treatment by replacing the heat-treatment process for the gasification of lithium and fluorine. In this paper, the disintegration process of the cobalt-based cathode electrode by hydrothermal treatment in pure water was investigated in detail and the feasibility of cobalt reclamation was also examined.

\section{Experimental}

\subsection{Preparation of $\mathrm{LiCoO}_{2}$ powder}

Commercially available $\mathrm{Li}_{2} \mathrm{CO}_{3}$ and $\mathrm{Co}_{3} \mathrm{O}_{4}$ powders were used as starting materials for the preparation of $\mathrm{LiCoO}_{2}$ powder. $\mathrm{LiCoO}_{2}$ was synthesized 
through the solid-state reaction technique reported by $\mathrm{R}$. Gupta and $\mathrm{A}$. Manthiram [6]. The $\mathrm{Li}_{2} \mathrm{CO}_{3}$ and $\mathrm{Co}_{3} \mathrm{O}_{4}$ were first mixed by rotary ball-milling with ethanol, and then dried at $333 \mathrm{~K}$ for $1 \mathrm{~h}$. An excess amount of about 3 $\mathrm{mol} \% \mathrm{Li}$ was added to the mixture to compensate for any loss of lithium that may occur during the firing. Then, the powder was precalcined in an $\mathrm{O}_{2}-\mathrm{N}_{2}$ stream (mole ratio of 20: 80) of for $5 \mathrm{~h}$ at $773 \mathrm{~K}$. After the pulverization by ballmilling, the mixture was calcined again in the stream of $\mathrm{O}_{2}-\mathrm{N}_{2}$ for $24 \mathrm{~h}$ at 1123 $\mathrm{K}$ to form $\mathrm{LiCoO}_{2}$. Finally, the agglomerated $\mathrm{LiCoO}_{2}$ was further pulverized by ball-milling to obtain powdery $\mathrm{LiCoO}_{2}$ for subsequent cathode preparation.

\subsection{Preparation of cathode electrode sample}

Commercially available conductive carbon black, poly(vinylidene fluoride) (abbreviated as PVDF) for a supporting binder, an aluminum foil for a current collector (purity 99.5\%, thickness: $10 \mu \mathrm{m}$ ) and the synthesized $\mathrm{LiCoO}_{2}$ powder were used for the components of a model cathode electrode sample.

The conductive carbon black, $\mathrm{PVDF}$ and $\mathrm{LiCoO}_{2}$ powders were, respectively mixed at the ratio of 10: 5: 85 mass $\%$ by ball-milling. Then, N, N-dimethylformamide was added to the mixture to form viscous slurry, and the resulting slurry was cast onto one side of the aluminum foil (size: $2 \times 2 \mathrm{~cm}$ ). The sample was cold-isostatically pressed at $200 \mathrm{MPa}$ for $1 \mathrm{~min}$, and then vacuum-dried at $393 \mathrm{~K}$. About $450 \mathrm{mg}$ of the mixture was cast onto the Al foil to ensure an enough amount of the treated sample for subsequent analyses.

\subsection{Hydrothermal treatment}

Hydrothermal treatment was conducted using a stainless steel vessel lined with poly(tetrafluoroethylene) (PTFE) in an inner volume of $60 \mathrm{~mL}$. A cathode electrode sample was placed into the vessel and then immersed with $30 \mathrm{~mL}$ of deionized and distilled water. The experiment was performed in the subcritical temperature range of $423-473 \mathrm{~K}$ for duration up to $40 \mathrm{~h}$. At any experiment, the heating and isothermal step was regulated by applying an external heating, but the cooling process was spontaneously done in ambiance. After the hydrothermal treatment, the solid component was collected by filtration using a membrane filter (pore size: $0.45 \mu \mathrm{m}$ ) under reduced pressure.

\subsection{Pyrometallurgical treatment}

Cobalt aluminates $\left(\mathrm{Co}\left(\mathrm{Co}_{\mathrm{x}} \mathrm{Al}_{2-\mathrm{x}}\right) \mathrm{O}_{4}, \mathrm{x}=0\right)$ were prepared from $\gamma-\mathrm{Al}_{2} \mathrm{O}_{3}$ (particle size $<20 \mathrm{~nm}$ ) and $\mathrm{Co}_{3} \mathrm{O}_{4}$ by referring to the paper reported by Casasdo and Rasines [7]. The synthesized $\mathrm{CoAl}_{2} \mathrm{O}_{4}$ was mixed with additives, such as $\mathrm{SiO}_{2}$, $\mathrm{CaCO}_{3}, \alpha-\mathrm{Al}_{2} \mathrm{O}_{3}$ and carbon black. The mixing molar ratio of $\mathrm{CaCO}_{3}: \mathrm{SiO}_{2}: \alpha-$ $\mathrm{Al}_{2} \mathrm{O}_{3}: \mathrm{CoAl}_{2} \mathrm{O}_{4}=1: 0.8: 0.2$ : 0.02 was applied for slag formation. The powders were mixed by ball-milling, uniaxially pressed into a pellet with diameter of 15 $\mathrm{mm}$, and then cold-isostatically pressed at $200 \mathrm{MPa}$ for $1 \mathrm{~min}$. The green compact was charged into a graphite crucible, muffled with carbon in mass quantities, and thermally treated in an electric furnace in Ar flow at $1623 \mathrm{~K}$ for 
$5 \mathrm{~h}$. This temperature was determined so as not only to reduce the $\mathrm{CoAl}_{2} \mathrm{O}_{4}$ but also to generate the liquid slag phase in the $\mathrm{CaO}-\mathrm{SiO}_{2}-\mathrm{Al}_{2} \mathrm{O}_{3}$ system by referring to the phase diagram in the ternary system of $\mathrm{CaO}, \mathrm{SiO}_{2}$ and $\mathrm{Al}_{2} \mathrm{O}_{3}$ [8], and the Richardson-Jeffes diagram for the each oxide [9].

\section{Results and discussion}

\subsection{Hydrothermal treatment of the cathode electrode}

Figure 1 shows the photographs of (a) as-prepared cathode and the hydrothermally treated specimens in $\mathrm{H}_{2} \mathrm{O}$ at $473 \mathrm{~K}$ for (b) 5 (c) 15 and (d) $40 \mathrm{~h}$. As-prepared cathode was collapsed depending on the treatment time; the cast mixture of $\mathrm{LiCoO}_{2}$, carbon black and PVDF was peeled off from the Al foil, and then was disintegrated into powdery particles; the Al foil became thinner and was broken apart with duration of the treatment. The fractured Al foil can be seen in the disintegrated mixture at the treatment time of $5 \mathrm{~h}$ (see Fig. 1(b); bright gray fragments are Al foil), but the foil disappeared completely when the treatment time was more than $15 \mathrm{~h}$ (see Figs. 1(c), (d)).
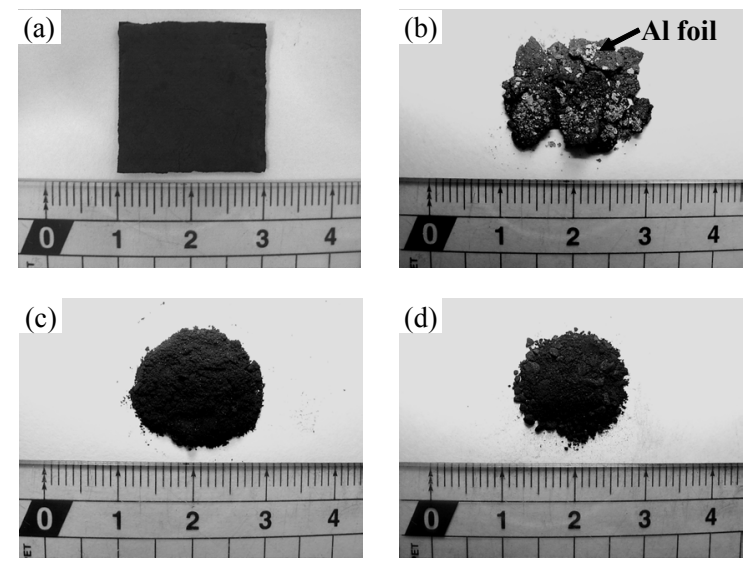

Figure 1: The appearance variation of the cathode electrodes though the hydrothermal treatments; (a) an untreated cathode and hydrothermally treated cathode for (b) 5, (c) 15 and (d) $40 \mathrm{~h}$ at 473 $\mathrm{K}$ in $\mathrm{H}_{2} \mathrm{O}$.

\subsubsection{Analyses of the solution after hydrothermal treatment}

Relationship between the $\mathrm{pH}$ values of ( $\boldsymbol{a})$ calculated and $(\boldsymbol{\Delta})$ measured of the solution after the hydrothermal treatment at $473 \mathrm{~K}$ for various times is shown in Figure 2. When the sample was immersed in water, the $\mathrm{pH}$ value of the solution increased immediately. Subsequently, the $\mathrm{pH}$ value increased gradually with increasing hydrothermal treatment time, and reached about 12 . The measured $\mathrm{pH}$ value almost corresponded to that of the calculated one according to the $\mathrm{Li}^{+}$ dissolution reaction [10]: 


$$
\mathrm{LiCoO}_{2}+5 \mathrm{H}_{2} \mathrm{O} \rightleftharpoons\left[\mathrm{Li}\left(\mathrm{H}_{2} \mathrm{O}\right)_{4}\right]^{+}+\mathrm{HCoO}_{2}
$$

Thus, the increasing behavior of $\mathrm{pH}$ value was mainly caused by the ionexchange and hydration reaction between $\mathrm{LiCoO}_{2}$ and $\mathrm{H}_{2} \mathrm{O}$ accompanying $\mathrm{Li}^{+}$ dissolution. Figure 3 shows the dissolution of lithium $\left(\mathrm{Li}^{+}\right)$, fluorine $\left(\mathrm{F}^{-}\right)$, aluminum $\left(\mathrm{Al}^{3+}\right)$ and cobalt $\left(\mathrm{Co}^{2+}\right.$ and $\left.\mathrm{Co}^{3+}\right)$ ions into the solution during the hydrothermal treatment. Fluorine ion was detected by the anionic chromatography, indicating that the cleavage of C-F bond in PVDF progressed on time and led to the formation of $\mathrm{F}^{-}$. A similar dissolution behavior between $\mathrm{Li}^{+}$and $\mathrm{F}^{-}$was observed; i.e., both dissolution amounts gradually increased, and then reached over 97 mass $\%$ at the treatment time of $20 \mathrm{~h}$. This trend resulted from $\mathrm{Li}^{+}$dissolution accompanied by the increase in $\mathrm{pH}$ value, because the hydrolytic cleavage of PVDF became more susceptible in higher concentrated alkali solution. The dissolution of cobalt ion was less than the detection limit by ICP-AES under the whole treatment conditions. The increase of $\mathrm{pH}$ value is also expected to have an effect on the $\mathrm{Al}$ foil corrosion because metal $\mathrm{Al}$ can dissolve into a high $\mathrm{pH}$ solution. As mentioned previously, the $\mathrm{Al}$ foil was fractured with increasing treatment time, and finally disappeared when the treatment time reached $15 \mathrm{~h}$ (see Fig. 1). However, the dissolution of $\mathrm{Al}^{3+}$ initially increased up to approximately 40 mass $\%$ until the treatment time of $10 \mathrm{~h}$, but successively decreased to approximately 2 mass $\%$ at the treatment time more than $20 \mathrm{~h}$. The reason for decreasing $\mathrm{Al}^{3+}$ dissolution will be deduced to the formation of $\mathrm{Co}\left(\mathrm{Co}_{\mathrm{x}} \mathrm{Al}_{2-\mathrm{x}}\right) \mathrm{O}_{4}$.

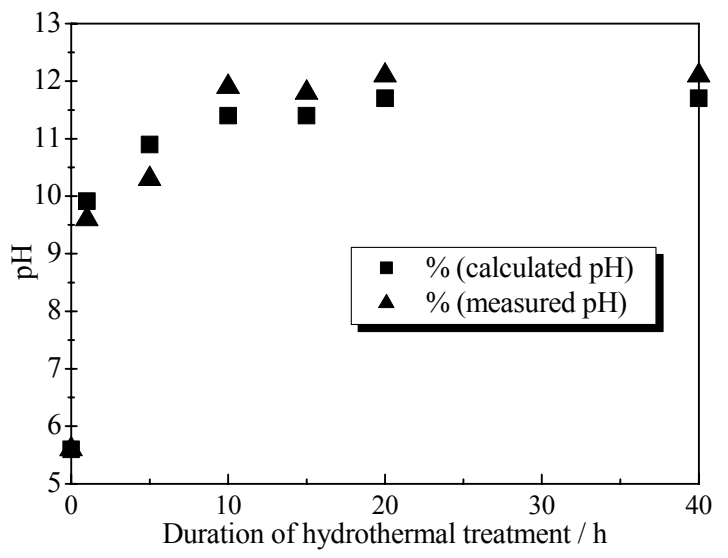

Figure 2: Relation between $(\boldsymbol{\bullet})$ the calculated and $(\boldsymbol{\Delta})$ the measured $\mathrm{pH}$ value of the solution after the hydrothermal treatments in $\mathrm{H}_{2} \mathrm{O}$ at $473 \mathrm{~K}$ for various treatment times.

With regard to the $\mathrm{Al}^{3+}$ dissolution, an electrolysis effect was considered to play an important role as another effect except for the $\mathrm{pH}$ factor. In order to examine this effect, the Al foil coated with or without PVDF was treated in 
various solutions at $473 \mathrm{~K}$ for $40 \mathrm{~h}$. The $\mathrm{Al}^{3+}$ dissolution result analyzed by ICPAES is listed in Table 1 . $\mathrm{NaCl}$ was chosen as an electrolyte instead of $\mathrm{LiOH}$ to avoid the $\mathrm{Al}^{3+}$ dissolution by the $\mathrm{pH}$ effect. These data showed that the $\mathrm{Al}$ foil was able to dissolve only when the foil with PVDF was treated in $\mathrm{NaCl}$ electrolytic solution (sample No. 1; the dissolution was nearly 76 mass\%). On the contrary, the $\mathrm{Al}$ foil without PVDF could not dissolve both in $\mathrm{H}_{2} \mathrm{O}$ and $\mathrm{NaCl}$ solutions (sample No. 3 and 4), and the foil with PVDF also could not dissolve in $\mathrm{H}_{2} \mathrm{O}$ (sample No. 2). Consequently, it was clarified that the electrolysis effect must be involved in the $\mathrm{Al}^{3+}$ dissolution process during the hydrothermal treatment under the electrolyte (e.g., $\mathrm{Li}^{+}$and $\left.\mathrm{OH}^{-}\right)$present conditions.

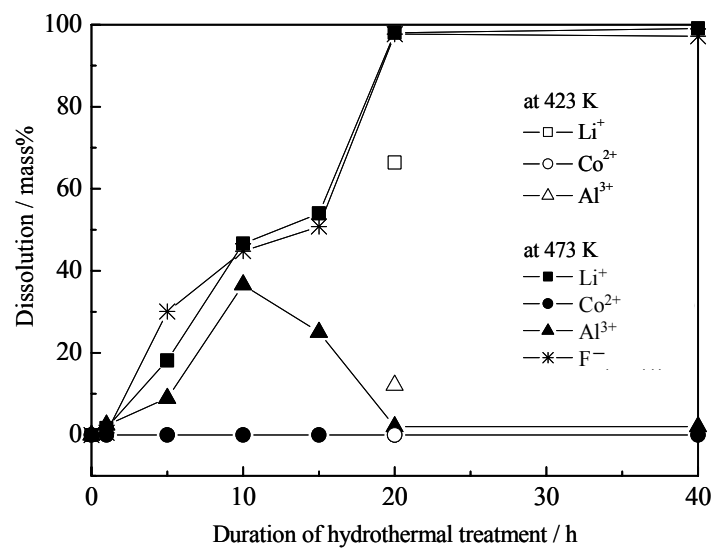

Figure 3: Dissolution of lithium, cobalt, aluminum and fluorine ions into the solution after the hydrothermal treatments of the cathode electrode at 423 and $473 \mathrm{~K}$ for various treatment times.

Table 1: $\quad \mathrm{Al}^{3+}$ dissolution from $\mathrm{Al}$ foil under hydrothermal condition.

\begin{tabular}{|c|c|c|c|}
\hline Sample No. & Sample $^{* 1)}$ & Solution & Dissolution (mass\%) \\
\hline 1 & Al foil with PVDF & $1 \mathrm{M} \mathrm{NaCl}$ aq. & 79.1 \\
\hline 2 & Al foil with PVDF & $\mathrm{H}_{2} \mathrm{O}$ & 0.1 \\
\hline 3 & Al foil & $\mathrm{H}_{2} \mathrm{O}$ & Not detected \\
\hline 4 & Al foil & $1 \mathrm{M} \mathrm{NaCl}$ aq. & Not detected \\
\hline
\end{tabular}

*1) Size of Al foil was $1 \times 1 \mathrm{~cm}$ for each sample.

\subsubsection{Analyses of the solid residues obtained after hydrothermal treatment}

Figure 4 shows XRD profiles of (a) the as-prepared cathode, and hydrothermally treated cathodes with $30 \mathrm{~mL}$ of deionized $\mathrm{H}_{2} \mathrm{O}$ for (b) 1, (c) 5, (d) 10, (e) 15, (f) 20 and (g) $40 \mathrm{~h}$. XRD profiles in Figs. 4(a) and (b) were acquired from the cathode surface cast by the mixture of $\mathrm{LiCoO}_{2}$, conductive carbon black and PVDF. Only peaks derived from the layered rock salt structure of $\mathrm{LiCoO}_{2}$ were detected on the as-prepared cathode. After the hydrothermal treatments for 1, 5, 10 and $15 \mathrm{~h}$, new peaks of hydrogen cobaltate $\left(\mathrm{HCoO}_{2}\right)$ and/or spinel-type cobalt aluminates $\left(\mathrm{Co}\left(\mathrm{Co}_{\mathrm{x}} \mathrm{Al}_{2-\mathrm{x}}\right) \mathrm{O}_{4}(0<\mathrm{x} \leq 2)\right)$ were identified in addition to $\mathrm{LiCoO}_{2}$ 
peaks, and an unknown peak at around $17^{\circ}$ (assigned as + ) appeared also for the samples treated for 5 and $10 \mathrm{~h}$. The unknown peak was derived from a reactant between the carbon black and $\mathrm{LiCoO}_{2}$ because the peak at around $17^{\circ}$ appeared when a green compact of carbon black and $\mathrm{LiCoO}_{2}$ mixture was treated under the above hydrothermal condition. Metallic Al peaks were observed in the process of the treatment for 5 and $10 \mathrm{~h}$ (Figs. 4(c) and (d)) due to the disintegration of the cathode sample, and the Al peaks entirely disappeared when the treatment time was $15 \mathrm{~h}$ and more (Figs. 4(e), (f) and (g)), which were in good agreement with the result of appearance change shown in Figure 1. Only a spinel-type $\mathrm{Co}\left(\mathrm{Co}_{\mathrm{x}} \mathrm{Al}_{2-\mathrm{x}}\right) \mathrm{O}_{4}(0<\mathrm{x} \leq 2)$ was formed when the treatment time was 20 and $40 \mathrm{~h}$, as seen in Figs. 4(f) and (g). Taking the ICP-AES and XRD results into consideration, it was implied that all cobalt existed in the solid phase, i.e., $\mathrm{LiCoO}_{2}, \mathrm{HCoO}_{2}$ or $\mathrm{Co}\left(\mathrm{Co}_{\mathrm{x}} \mathrm{Al}_{2-\mathrm{x}}\right) \mathrm{O}_{4}$, depending on the treatment time. It was found that a spinel-type $\mathrm{Co}_{3} \mathrm{O}_{4}$ with no $\mathrm{Al}$ formed from a green compact of $\mathrm{LiCoO}_{2}$ and carbon black mixture by a hydrothermal treatment. The diffraction peaks of $\left(\mathrm{Co}\left(\mathrm{Co}_{\mathrm{x}} \mathrm{Al}_{2-\mathrm{x}}\right) \mathrm{O}_{4}\right)$ and $\mathrm{Co}_{3} \mathrm{O}_{4}$ could not be distinguished each other because their peaks generally overlapped.

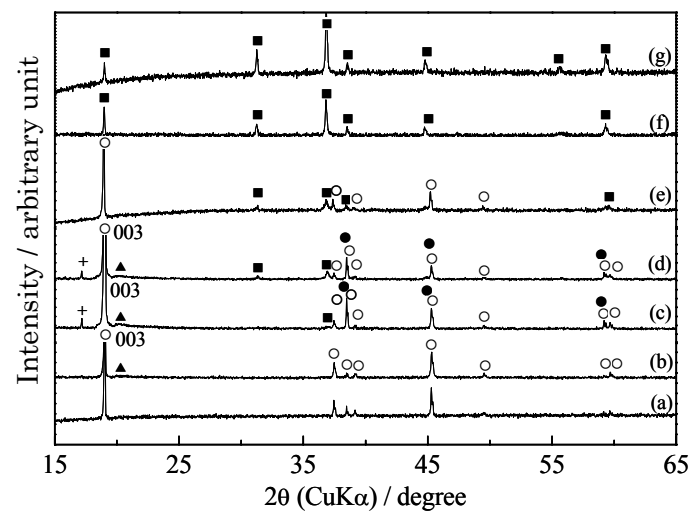

Figure 4: XRD profiles of (a) as-prepared cathode, and hydrothermally treated cathodes in $\mathrm{H}_{2} \mathrm{O}$ at $473 \mathrm{~K}$ for (b) 1 , (c) 5, (d) 10, (e) 15, (f) 20 and $(\mathrm{g}) 40 \mathrm{~h}$. Symbols are $(\boldsymbol{\square}) \mathrm{Co}\left(\mathrm{Co}_{\mathrm{x}} \mathrm{Al}_{2-\mathrm{x}}\right) \mathrm{O}_{4}(0<\mathrm{x} \leq 2)$, ( $\left.\square\right)$ $\mathrm{Co}_{3} \mathrm{O}_{4},(\bullet) \mathrm{Al},(\circ) \mathrm{LiCoO}_{2},(\boldsymbol{\Delta}) \mathrm{HCoO}_{2}$ and (+) unknown peak.

Figure 5 shows representative (a) secondary electron image (SEI), and EDX element maps corresponding to (b) $\mathrm{Co}$, (c) $\mathrm{O}$, (d) $\mathrm{Al}$ and (e) $\mathrm{C}$ on the hydrothermally treated cathode. The EDX maps clearly verified that particles consisting of $\mathrm{Co}, \mathrm{Al}$ and $\mathrm{O}$ existed in the treated cathode, while particles consisted of carbon were originated from carbon black and PVDF. Although the $\mathrm{Co}\left(\mathrm{Co}_{\mathrm{x}} \mathrm{Al}_{2-\mathrm{x}}\right) \mathrm{O}_{4}$ particles were confirmed by the EDX analysis, the $\mathrm{Co}_{3} \mathrm{O}_{4}$ particles were not observed. The hydrothermally treated cathode was believed to contain $\mathrm{Co}_{3} \mathrm{O}_{4}$ particles, but the amount of $\mathrm{Co}_{3} \mathrm{O}_{4}$ seemed too small to be identified by EDX analysis. 

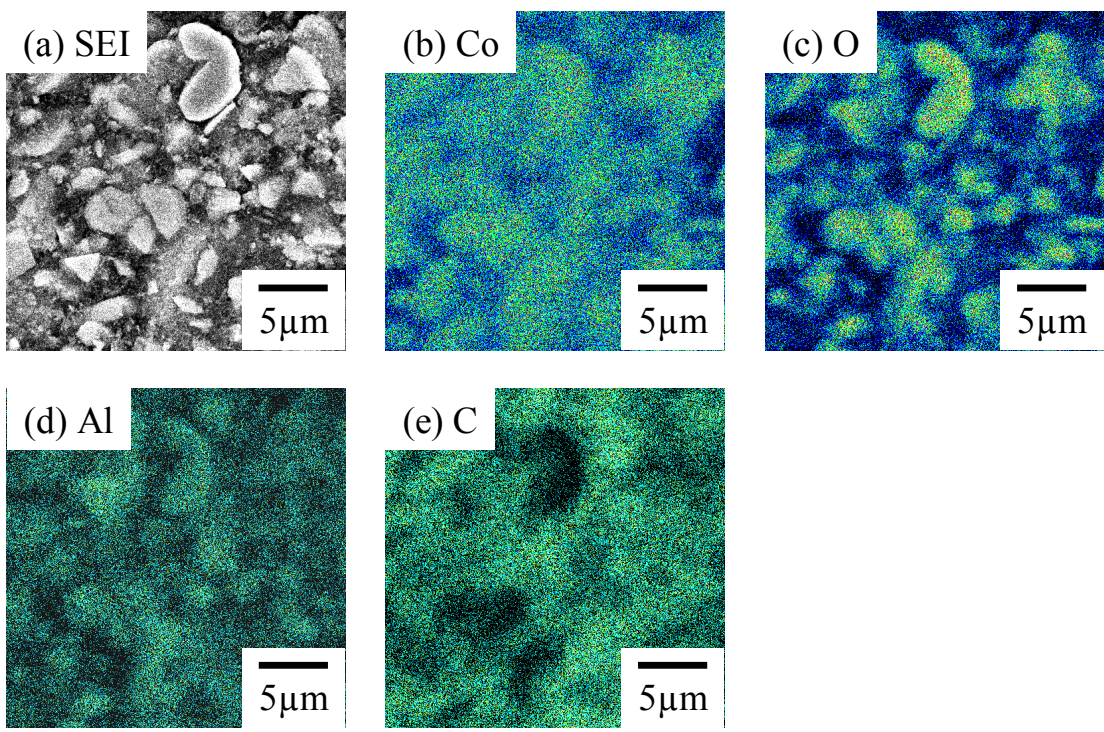

Figure 5: Representative (a) secondary electron image (SEI) and element distributions of (b) $\mathrm{Co}$, (c) $\mathrm{O}$, (d) Al, and (e) $\mathrm{C}$ on hydrothermally treated cathode at $473 \mathrm{~K}$ for $40 \mathrm{~h}$.

\subsubsection{Optimum condition of hydrothermal treatment}

The hydrothermal treatment at $423 \mathrm{~K}$ for $20 \mathrm{~h}$ was carried out in order to lower the treatment temperature, but the $\mathrm{Li}^{+}$dissolution was found insufficient (see Figure 3). Therefore, it was found that the treatment temperature at $473 \mathrm{~K}$ or more was required for the separation of $\mathrm{Li}$ from $\mathrm{Co}$ and Al. Taking the results of ICP-AES, IC, XRD and XPS analyses into consideration, the hydrothermal treatment at $473 \mathrm{~K}$ for $20 \mathrm{~h}$ was determined as an optimum condition for the separation of $\mathrm{Li}$ and $\mathrm{F}$ from the cathode electrode, when more than 99.9 mass\% of $\mathrm{Co}$ and 98 mass\% of $\mathrm{Al}$ were efficiently reclaimed as a form of solid-state $\mathrm{Co}\left(\mathrm{Co}_{\mathrm{x}} \mathrm{Al}_{2-\mathrm{x}}\right) \mathrm{O}_{4}(0<\mathrm{x} \leq 2)$, and most of $\mathrm{Li}$ and $\mathrm{F}$ could be dissolved into the solution. XPS analysis exhibited that no fluorine was detected on the solid residue after the hydrothermal treatment over $20 \mathrm{~h}$, corresponding to the result of $\mathrm{F}^{-}$dissolution shown in Fig. 3. Residual carbon analysis by CHN coder revealed that the recovered spinel compound contained nearly 12 mass $\%$ of carbon, which originated from the conductive carbon black and PVDF. This carbon contamination has no problem in the subsequent pyrometallurgical treatment because the carbon can be used as a reductant.

\subsection{Recovery of metal cobalt by pyrometallurgical method}

Figure 6 shows XRD profiles of the mixture of $\mathrm{SiO}_{2}, \mathrm{CaCO}_{3}, \alpha-\mathrm{Al}_{2} \mathrm{O}_{3}, \mathrm{CoAl}_{2} \mathrm{O}_{4}$ and carbon black before (a) and after (b) a pyrometallurgical treatment at $1623 \mathrm{~K}$ for $5 \mathrm{~h}$ in Ar flow. The peaks of $\mathrm{SiO}_{2}, \mathrm{CaCO}_{3}, \alpha-\mathrm{Al}_{2} \mathrm{O}_{3}$ and $\mathrm{CoAl}_{2} \mathrm{O}_{4}$, which were the components of the starting mixture, were identified in Fig. 6(a). On the 
other hand, the peaks of calcium silicate, larnite, gehlenite and metallic cobalt were identified with no peaks of the starting components, as seen in Fig. 6(b). Hence, by adding the $\mathrm{SiO}_{2}, \mathrm{CaCO}_{3}$ and $\alpha-\mathrm{Al}_{2} \mathrm{O}_{3}$ to the $\mathrm{CoAl}_{2} \mathrm{O}_{4}$ and carbon black mixture, we succeeded in incorporating $\mathrm{Al}$ into the slag phase and obtaining the metallic Co without formation of any alloy. The effect of such additives is explained by the difference in Gibbs free energy change for the formation of each oxide from metallic Co and Al. As generally known, the more negative a free-energy change for oxidation is, the easier the formation of an oxide is. The free energy change for the formation of aluminum oxide is more negative than that for the formation of cobalt oxide according to the Richardson-Jeffes diagrams [9]. In addition, $\alpha-\mathrm{Al}_{2} \mathrm{O}_{3}$ can form a liquid slag phase with the additives at $1623 \mathrm{~K}$ in terms of the equilibrium phase diagram of the $\mathrm{SiO}_{2}-\mathrm{CaO}$ $\mathrm{Al}_{2} \mathrm{O}_{3}$ system [8]. Thereupon, $\mathrm{Al}$ was transferred into the slag phase and Co was separated as a pure metal.

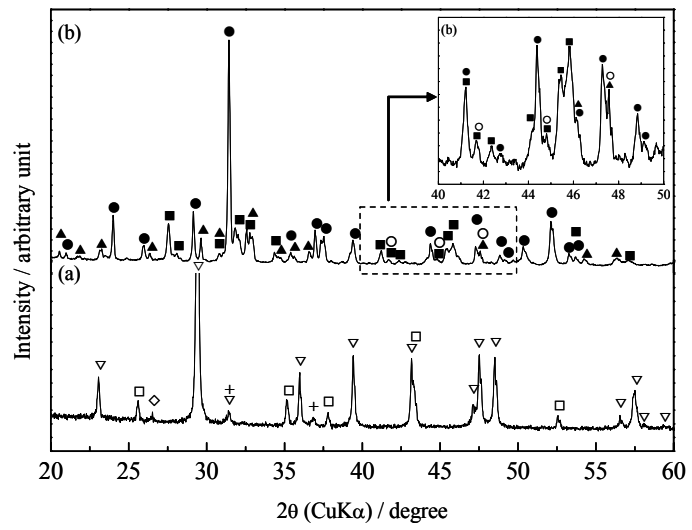

Figure 6: XRD profiles of the mixture (a) before and (b) after a pyrometallurgical treatment at $1623 \mathrm{~K}$ for $5 \mathrm{~h}$. Symbols are $(\diamond)$ $\mathrm{SiO}_{2},(\quad) \mathrm{CaCO}_{3},(\square) \alpha-\mathrm{Al}_{2} \mathrm{O}_{3},(+) \mathrm{CoAl}_{2} \mathrm{O}_{4},(\bullet) \mathrm{Ca}_{2} \mathrm{Al}_{2} \mathrm{SiO}_{7}$ (gehlenite), ( $\mathbf{\Delta}) \mathrm{Ca}_{2} \mathrm{SiO}_{4}$ (calcium silicate), (ロ) $\mathrm{Ca}_{2} \mathrm{SiO}_{4}$ (larnite) and (०) Co.

Considering the results of the hydrothermal and the pyrometallurgical treatments, we propose a novel cobalt recovering process. This new process consisted of two stages; the first is the hydrothermal treatment for the dissolution of $\mathrm{Li}$ and $\mathrm{F}$ into the solution and the second is the pyrometallurgical treatment for the reduction and condensation of cobalt from the spinel compound. It is quite obvious that the hydrothermal treatment can operate at temperatures lower than the present pyrometallurgical process for the gasification of $\mathrm{Li}$ and $\mathrm{F}$ with no corrosive gas generation and with no utilization of toxic or expensive solvents such as acid or alkali solution. Thus, a cost for equipment maintenance of damaged furnace wall is expected to be reduced by preventing the corrosive gas generation. Additionally, the energy consumption in hydrothermal treatment can be compensated by the utilization of waste heat generated from the subsequent pyrometallurgical treatment. In the second pyrometallurgical step, the present- 
operating furnace is probably utilized without any modification, which means that an investment for new equipments is expected to be reduced. Therefore, taking all advantages into account, this new process can be recommended as an environmental-friendly and low-cost process.

\section{Summary}

(1) Metallic cobalt was successfully reclaimed from a cathode electrode by a hydrothermal treatment in pure water at $473 \mathrm{~K}$ for $20 \mathrm{~h}$ and subsequent pyrometallurgical treatment at $1623 \mathrm{~K}$ for $5 \mathrm{~h}$ under Ar flow.

(2) More than 99.9 mass $\%$ of Co and 98 mass \% of $\mathrm{Al}$ in the cathode sample was converted to solid state spinel $\mathrm{Co}\left(\mathrm{Co}_{\mathrm{x}} \mathrm{Al}_{2-\mathrm{x}}\right) \mathrm{O}_{4}(0<\mathrm{x} \leq 2)$ and most of $\mathrm{Li}$ and $\mathrm{F}$ could be dissolved in the solution after the hydrothermal treatment under the optimum condition at $473 \mathrm{~K}$ for $20 \mathrm{~h}$.

(3) The hydrothermal treatment for the separation of $\mathrm{Li}$ and $\mathrm{F}$ in the cathode electrode could lower the treatment temperature from $1273 \mathrm{~K}$ to $473 \mathrm{~K}$ with no corrosive gas generation and with no utilization of toxic and expensive solvents.

\section{References}

[1] Rdyh, C.J. \& Svard, B., Impact on global metal flows arising from the use of portable rechargeable batteries. The Science of the Total Environment, 302, pp. 167-184, 2003.

[2] Castillo, S., Ansart, F., Laberty-Robert, C. \& Portal, J., Advances in the recovering of spent lithium battery compounds. J. Power Sources, 112, pp. 247-254, 200.

[3] Lain, M.J., Recycling of lithium ion cells and batteries. J. Power Sources, 97-98, pp. 736-738, 2001.

[4] Zhang, P., Yokoyama, T., Itabashi, O., Suzuki, T.M. \& Inoue, K., Hydrometallurgical process for recovery of metal values from spent lithium-ion secondary batteries. Hydrometallurgy, 47, pp. 259-271, 1998.

[5] Nan, J., Han, D. \& Zuo, X., Recovery of metal values from spent lithiumion batteries with chemical deposition and solvent extraction. J. Power Sources, 152, pp. 278-284, 2005.

[6] Gupta, R. \& Manthiram, A., Chemical extraction of lithium from layered $\mathrm{LiCoO}_{2}$. J. Solid State Chemistry 121, pp. 483-491, 1996.

[7] Casasdo, P.G. \& Rasines, I., The series of spinels $\mathrm{Co}_{3-\mathrm{S}} \mathrm{Al}_{\mathrm{S}} \mathrm{O}_{4}(0<\mathrm{S}<2)$ : study of $\mathrm{Co}_{2} \mathrm{AlO}_{4}$. J. Solid State Chemistry, 52, pp. 187-193, 1984.

[8] Levin, E.M., McMurdie, H.F. \& Hall, F.P., in: Phase Diagrams for Ceramists, American Ceramic Society: Columbus, Ohio, pp. 313-326, 1956.

[9] Gaskell, D.R., in: Introduction to Metallurgical Thermodynamics, Second Edition, Hemisphere Publishing Corporation: UAS, 1981.

[10] Watanabe, T., Uono, H., Song, S-W., Han, K-S. \& Yoshimura, M., Direct fabrication of lithium cobalt oxide films on various substrates in flowing aqueous solutions at $150{ }^{\circ}$ C. J. Solid State Chem., 162, pp. 364-370, 2001. 